\title{
Human Skin Reflects Air Pollution - a Review of the Mechanisms and Clinical Manifestations of Environment-Derived Skin Pathologies
}

\author{
Marta Denisow-Pietrzyk* \\ ${ }^{1}$ Department of Dermatology, $1^{\text {st }}$ Military Clinical Hospital with the Outpatient Clinic in Lublin, \\ 20-049 Lublin, Racławickie 23 Str. Poland \\ ${ }^{2}$ Department of Didactics and Medical Simulation, Medical University of Lublin, \\ 20-093 Lublin, Chodźki 4 Str., Poland
}

Received: 28 June 2020

Accepted: 16 November 2020

\begin{abstract}
Development of urbanization, transport, and industry contributes to a constant increase in airborne pollution levels worldwide. There are more than 2000 different chemical substances emitted into the air. Among air pollutants, particulate matters PMs, volatile organic compounds (VOCs), $\mathrm{CO}_{2}, \mathrm{CO}, \mathrm{NO}_{2}$, $\mathrm{SO}_{2}$, ground-level ozone $\mathrm{O}_{3}$ metals, and persistent organic pollutants POPs have been found to exert harmful effects on human skin. The exposure to the increasing levels of air pollution may worsen skin problems and severe diseases in millions of people worldwide, leading to the growth of health care costs. Under permanent exposure to air pollutants, the redox homeostasis in skin cells is impaired. Airborne pollutants penetrating the skin activate a protein - aryl hydrocarbon receptor (AhR) and trigger a cascade of reactions in which high levels of reactive oxygen species (ROS) are generated. The redox imbalance modulates lipids peroxidation, oxidation of proteins, and DNA damage. Airborne stressors can be manifested as clinical dermatological problems, i.e. skin aging, imbalance in skin microbiota, increase in inflammatory reactions (allergy, acne, atopic dermatitis, eczema), or even cancer. Therapeutic strategies to counteract skin damage should be targeted at reducing free radical formation and scavenging free radicals in the skin cells. Moreover, the restoration of the skin barrier function and an increase in antioxidant reserves and reducing chronic inflammation are of great importance. A forward-looking area of research is then to fill the gaps about the effect of air pollutants on the skin, including skin carcinogenesis.
\end{abstract}

Keywords: airborne toxins, oxidative stress, inflammation, dermatitis, skin cancer

*e-mail: marta.denisow@gmail.com 


\section{Introduction}

Skin, the outermost layer of the human body, is continuously threatened by the harmful external environment. Therefore, one of the most critical functions of skin is to create a barrier against external stressors and serve sensation and metabolic functions $[1,2]$.

The major contamination types that are harmful to human health include water pollution, air pollution, soil pollution, light pollution, and noise pollution [3]. Among these, air pollution is particularly damaging to skin [4].

According to the World Health Organization (WHO), air pollution is contamination of indoor and outdoor air by chemical, physical, and biological agents that modify the neutral nature of the atmosphere [5]. Several air pollutants are produced naturally (i.e. woodland fires, volcanic eruptions); however, most pollutants originate from human activity [6]. Among the well-known causes of anthropogenic air pollutants, there are industrial processes, i.e. coal-burning power plants, traditional house heaters, open waste burning, transport, and agricultural activity, i.e. application of fertilizers, herbicides, livestock farming, and rice paddies $[5,7,8]$.

Air pollutants are classified as primary pollutants (emitted directly to the air) and secondary pollutants (formed by reactions involving primary pollutants and other atmosphere constituents) [8]. The chemical composition of air pollution depends on various factors, including climate, geographic location, topography, land use, and origin [9].

In the last decade, an increase in air pollution has been noted in many parts of the world [5]. For example, air pollution in the United States of America (USA) has increased nationally since 2014, presumably reversing a decades-long trend toward clean air [10]. According to the European Union (EU) report, poor air quality caused 412,000 deaths in Europe in 2016 [8]. Approximately $98 \%$ of the population in Asia and the Pacific region are exposed to contaminated air and 99 of the 100 most populated cities in the world are located in Asia-Pacific countries, which reflects the air pollution of the transition phase of industrialization and urbanization within the developing countries [5].

Epidemiological data indicate that exposure to air pollutants can negatively affect many human systems (i.e. respiratory, nervous, cardiovascular). The latest evidence underlines that long-term or chronic exposure to air pollutants may bring various clinical outcomes i.e. breathing problems, asthma, chronic obstructive pulmonary disease, diabetes, hypertension, impaired heart rate variability, and inflammatory and dermatological diseases [11-14]. There is even evidence for an increase in daily mortality (2-3\%) associated with high concentrations of airborne particles and gaseous toxins in several Western European cities [11, 13, 15].

The skin is recognized as a second (after the respiratory tract) most frequent route by which airborne particles and toxins can enter into the body [6, 16]. Even single contact of air pollutants with the skin may induce skin redness. Moreover, long-term airborne stressors can be demonstrated as clinical dermatological problems, i.e. skin aging, increase in inflammatory reaction, allergic and irritant dermatitis, eczema, acne, or even cancer [3, 4, 17-21]. For example, the frequency of atopic dermatitis has been gradually increasing over the last decades in Europe, in particular in children inhabiting areas with high levels of pollutants [22].

In addition to air pollutants, skin is subjected to solar ultraviolet radiation - UVA and UVB [23]. There is also evidence that combined effects of air pollutants and UV radiation can significantly increase the risk of skin cancer [24,25]. The excessive exposure to UV radiation brings profound risks to skin, i.e. atrophy, changes of pigmentation, wrinkling and malignancy [24]. UV radiation related molecular changes in the skin cells are linked to basal cell carcinoma, squamous cell carcinoma and malignant melanoma [23].

The aim of this review report is to understand the structure and function of skin layers that provide a cellular and molecular base for barrier function, skin homeostasis, and regulation of skin metabolism to protect against extrinsic environmental agents. The biology of the epidermis and the mechanisms by which airborne pollution interacts with the skin have been considered. Moreover, we have focused on the current state of knowledge of the association of air pollution with clinical manifestations of its harmful effects on the skin and to establish the possible link between air pollution and skin disorders.

\section{Material and Methods}

The review protocol is based on references available in various databases: Annual Reviews, BioMed, BMJ Group, Central BMJ Group, Elsevier, Hindawi, Oxford Academic, NCBI, PubMed, ScienceDirect, and Taylor $\&$ Francis. The keyword combinations included the following phrases: 'air pollution', 'airborne pollution', 'skin condition', 'skin structure' 'cutaneous/skin disorders', 'oxidative stress and skin', 'air pollution and reactive oxygen species', 'air pollution and skin', 'environmental stressors and skin', 'pollution and aging' 'pollution and inflammation', 'pollution and acne', and 'pollution and atopic dermatitis'. In total, 128 relevant original and review papers have been reviewed to establish the possible link between air pollution and skin disorders.

\section{Functional Structure and Biochemically Active Compounds of Skin}

Skin is a multi-layered, highly specialized organ composed of the epidermis, the dermis (connective tissues), and the hypodermis (adipose tissues). There are also other structures, i.e. hair follicles, glands, nerves, 
and lymphatic and blood vessels [26, 27]. The skin function is supported by direct communication between epidermal and dermal compartments through signaling pathways [28].

In humans, the epidermis is segmented into specific anatomic structures that represent particular physical, biochemical, and immune functions [27]. The organization of the epidermis is dynamic and its tissues are self-renewable [29, 30].

The epidermis is mainly composed of flatted nonvascularized keratinocytes, i.e. keratin-producing cells. Keratin is an intracellular fibrous protein; it is most abundant in epithelial cells, in which the protein forms a network of structural intermediate filaments (IFs) [31]. Keratinocytes constitute at least $80-90 \%$ of the epidermis cells [27]. They differentiate from the cells in the basal layer and migrate to the surface of skin [32]. Keratinocytes are known to synthetize and secrete diverse peptides and free fatty acids to ensure skin barrier function [33]. According to their histology, four major sub-layers of keratinocytes have been distinguished [28]. From the outside to the inside, these layers are stratum corneum (SC), stratum granulosum (SG), stratum spinosum (SS), and stratum basale (SB).

The stratum corneum (SC), i.e. the most superficial layer of the epidermis, represents a primary barrier to external agents and is a part of the first immune body defense [28]. The SC layer is based on cells and a matrix arranged in a "brick and mortar" model [34]. The "bricks" are composed of non-viable cells corneocytes. These SC cells are generated from the cell-death products of the SG layer [28]. A classical apoptosis mechanism (called cornifications) is involved in the formation of SC [29]. Corneocytes are connected via corneodesmosomes (lamellar bodies; LB). The cells are surrounded by the "mortar" - a complex of lipids, proteins, glycoproteins, hydrolytic enzymes, and protease inhibitors [34]. These compounds are biochemically active and provide the physical barrier function of the skin $[16,35,36]$. The physical barrier protects the skin against water loss and forms a defense system against diffusion and infiltration of environmental pollutants into the epidermis [37]. The chemical complex of SC protects the skin against microorganisms [1,38,39]. Accordingly, with its configuration, the stratum corneum can act as a membrane that easily responds to environmental conditions [28, 30, 40].

Stratum corneum (SC) lipids are mainly present in the extracellular matrix. They are composed of ceramids (50\% of lipids mass), cholesterol (25\%), and free fatty acids (15\%) [28]. The lipids control water flux and regulate the degree of transepidermal water loss (TEWL) [41]. In the lipid mixture, squalene (a triterpene), which is an intermediate in the cholesterol biosynthesis pathway, is regarded as essential for skin lubrication [42]. Squalene is recognized as the most sensitive molecule to singlet oxygen and induced peroxidation.
Imbalances in lipid metabolism and transport cause serious problems in the epidermis barrier function and complications in maintenance of homeostasis [37, 43-46].

SC proteins are mainly composed of loricrin making up $\sim 80 \%$ of protein mass, small proline-rich protein constituting $\sim 8 \%$, and filaggrin accounting for $6 \%$ [47]. Involicrin, periplakin, and envoplakin have been identified as well [48]. All these proteins are involved in the barrier function of the epidermis [47-49]. A fundamental role in skin protection against the external environment (smog, UV, reactive oxygen species) is ascribed to filaggrin, i.e. a histidine-rich protein [50]. Filaggrin has filament aggregating properties and binds to keratin filaments [51]. Consequently, tight bundles are formed, and granular cells are disrupted [52]. Numerous studies have pointed out the significance of filaggrin in skin homeostasis $[49,53,54]$. In 2006, a gene sequence encoding filaggrin was identified [52]. Since then, abnormal expression of filaggrin protein has been noted under environmental oxidative stress $[55,56]$. In murine models, overexpression of filaggrin was found to lead to a delay of epidermal barrier restoration [57].

Just beneath the SC, lies the stratum granulosum (SG) layer. It contains living cells with abundant keratohyalin granules in their cytoplasm [27, 28]. The SG cells form a barrier against soluble proteins, i.e. immunoglobulins and bacterial toxins [58]. The stratum spinosum consists of 8-10 layers of keratinocytes with a limited capability of cell division and Langerhans cells (at a ratio $\sim 1: 50$ with keratinocytes). The Langerhans cells are responsible for immune response (inflammation/tolerance), preventing unnecessary and harmful immune activation $[59,60]$.

The stratum basale (SB) is the deepest epidermis layer composed of mitotically active stem cells that produce keratinocytes [26, 27]. The other cell types in SB are Merkel cells (function as sensory receptors) and melanocytes (cells producing the melanin pigment). Melanin is responsible for the skin and hair color and helps to protect the epidermis cells against the harmful effect of UV radiation [61]. The SB layer is separated from the dermis by the basal lamina [27].

The next skin layer beneath the epidermis is the dermis. The dermis is composed of dense irregular connective tissue and is organized into two layers: (i) the superficial papillary region and (ii) the deeper reticular dermis. The dermis contains also skin appendages, i.e. hair follicles, sebaceous glands (oil glands), sweat and apocrine glands, and thermo- and mechanoreceptors. These structures are important for thermoregulation and contact with the environment $[26,27]$. The dermis is a vascularized (contains both blood and lymphatic vessels) and innervated skin layer.

The proper skin function and regulation of its homeostasis require constant communication between major skin compartments. The function and expression of skin molecules are under the control of cytokines and intercellular signaling molecules, which establish a complex of metabolic and signaling networks to 
accomplish homeostasis and proper development of the epidermal barrier $[25,54,59,60,62]$. In normal skin state, cell growth and differentiation as well as tissue repair are in balance required for the normal biological function of skin $[19,50,53]$.

\section{Major Airborne Pollutants Harmful for the Skin}

In terms of human health and skin condition, air toxicants exert harmful effects, depending on the time of exposure, gender, and age [1,63]. With regards to skin, there are four main categories of air pollutants (i) particulate matters - PMs, (ii) toxic gaseous pollutants, (iii) metals, and (iv) persistent organic pollutants POPs $[5,9]$.

Particulate matters (PMs) are categorized according to their "aerodynamic diameter" as ultrafine particles - UFP $(<0.1 \mu \mathrm{m})$, fine particles - PM2.5 $(<2.5 \mu \mathrm{m})$, and coarse particles - PM10 $(<10 \mu \mathrm{m})$. In the atmosphere, PMs form a complex of small particles and liquid droplets [9]. In addition, the surface of PMs can be rich in metals, acids, organic chemicals, and other transition elements, i.e. soil or dust particles [64].

PMs have been indicated among most serious air pollutants in Europe [4, 8]. In particular, fine-size airborne particles (PM2.5) originating mainly from traffic sources are extremely reactive towards epidermis $[9,21]$. The toxic gaseous pollutants include volatile organic compounds (VOCs), $\mathrm{CO}_{2}, \mathrm{CO}, \mathrm{NO}_{2}, \mathrm{SO}_{2}$, and ground-level ozone $\mathrm{O}_{3}$. Volatile organic compounds (i.e. benzene, toluene, xylene) are important elements, which play a crucial role in the formation of ground ozone. Moreover, ozone formation is favored by fine particulate matter and photochemical smog. Among metals, lead, cadmium, chromium, nickel, and zinc are the most frequent airborne pollutants [65]. There are reports of considerable toxicity of airborne metals on the skin [19]. Persistent organic pollutants POPs are a group of organic compounds, i.e. pesticides, dioxins, furans, and polycyclic aromatic hydrocarbons (PAHs) [5,9]. POPs that occur in air dust have highly bioaccumulative properties and can bind with cell macromolecules [21].

Among air pollutants, PMs, VOCs, and PAHs have been indicated as the most serious airborne contaminants in Europe [4, 8]. However, other air pollutants can induce chronic human health risks as well and have been recognized as extremely toxic to the skin [16]. In fact, contaminated air can contain over 2000 different chemicals and compounds that can strongly influence the development of serious skin pathologies $[4,6]$.

\section{Mechanism of Air Pollutant Toxicity to the Skin}

It has been widely documented that air pollutants can use two pathways to enter the skin i.e. by direct contact of the stratum corneum or hair follicles with toxins or via an indirect way with the systemic blood distribution of inhaled toxins [66, 67]. Different studies have shown that the penetration of the skin by environmental pollutants involves the aryl hydrocarbon receptor $(\mathrm{AhR})$ protein [68]. The protein has been found to be expressed on the surface of keratinocytes of stratum basale, melanocytes, and Langerhans cells [69].

Air pollutants (PMs, PAHs, metals, ozone) can easily bind to AhR, which triggers a cascade of reactions related to oxidative stress [70]. As a result, overproduction of reactive oxygen species (ROS) occurs. ROS are small reactive molecules containing oxygen (i.e. $\mathrm{O}_{2}^{-}, \mathrm{OH}, \mathrm{O}_{3}, \mathrm{H}_{2} \mathrm{O}_{2}$ ). At physiological levels, ROS are generated as typical byproducts of the electron transport chain during mitochondrial respiration of aerobic organisms and are delivered from peroxisomal metabolism [71]. Moreover, at low levels, ROS production is in dynamic stability and mediates a number of significant cell functions [17]. In normal state, the skin is in redox homeostasis enhancing normal metabolism and cell proliferation, growth, repair, and restoration [72].

The ROS production is controlled by an integrated antioxidant defense system neutralizing the oxidation effects [72]. The major cellular antioxidants include enzymatic substances: superoxide dismutase (SOD), catalase (CAT), glutathione peroxidase (GPx), and DT-diaphorase enzymes. Moreover, non-enzymatic substances, i.e. carotenoids, ascorbic acids, vitamin E, glutathione, retinoids, albumin, uric acid, and bilirubin serve as scavengers of different forms of ROS [48, 73].

Indeed, it is increasingly being recognized that air pollutants (PM, PAHs, VOCs) may lead to an overall increase in intracellular ROS levels in skin cells through abnormal activation of nicotinamide adenine dinucleotide phosphate (NADPH) oxidases or cytochrome enzymes [42,74]. A permanent highROS state provokes oxidation of major macromolecules (lipids, proteins), promotes depletion of antioxidants (Vit. E, cholesterol), and decreases the levels of squalene and the squalene/lipid ratio [73, 75].

Although the molecular mechanism by which ROS interfere with skin function is not fully understood, the disturbance in redox homeostasis in epidermal cells is recognized as crucial in skin cell damage $[48,70]$. Other investigations report a connection between macromolecules oxidation/peroxidation and various pathological skin states [74, 76]. Elevated ROS perturb the structure and dynamics of the cellular membrane, resulting in an increase in water permeability, a decrease in lipid bilayer thickness, or alteration in lipid membrane order and fluidity [77]. Generation of ROS induces protein oxidation, which prevents deoxyribonucleic acid (DNA) replication and transcription. In consequence, these processes increase the risk of DNA damage in epidermal keratinocytes, which leads to impaired cellular function [78]. Increased levels of ROS induced by PMs promote the replication of damaged DNA fragments and/or inhibit 
repair mechanisms, resulting in DNA mutations [79]. Nevertheless, numerous studies have shown that the imbalance in ROS initiates abnormal metabolism of skin cells and can induce skin inflammation. Finally, the cell immunity and cell repair capacity are decreased, which can promote carcinogenesis [80]. At present, it is increasingly being recognized that cellular response to elevated ROS is a complex process involving both rapid and delayed biochemical reactions to exposure to redox stressors [77].

Remarkably, ROS generated upon skin contact with air pollutants stimulate protein kinases that phosphorylate the activator protein 1 (AP-1) transcription factor, which in turn results in upregulation of matrix metalloproteinases (MMPs) contributing to degradation of skin collagen [81]. More studies have also reported that air pollutants upregulate the levels of proinflammatory cytokines (tumor necrosis factor- $\alpha$ : TNF- $\alpha$, interleukins: IL- 6 , IL-1 $\alpha$ ) in epidermis keratinocytes, leading to infiltration of activated neutrophils and phagocytic cells [69, 82, 83]. Chronic cytokine oversecretion may modify the function of skin proteins involved in the formation of the stratum corneum, i.e. loricrin and profilaggrin/filaggrin, thereby causing degradation of the physical barrier of the skin $[38,50,52]$. High cytokine levels contribute to a general inflammatory response and tissue damage $[40,62]$.

The airborne PMs, VPCs, and $\mathrm{NO}_{2}$ pollutants lead to an increase in cytokines in keratinocytes and oxidation of molecules in the stratum corneum [83]. It is generally assumed that exposure to these airborne particles and molecules can induce irreversible changes associated with various pathologies in both the epidermis and dermis [79, 84]. Importantly, environmental stressors change the molecular and physiological skin characteristics and modify the appearance and structure of skin $[4,56,80,85,86]$. There are many lines of evidence for an increase in transepidermal water loss after chronic exposure to air pollutants, which results in skin dryness [87]. The efficiency of penetration of environmental particles into the skin depends on their diameter [67]. In the group of airborne pollutants PMs, especially small-size particles (PM2.5) are highly reactive towards skin and can directly interact with the outer parts of the epidermis (stratum corneum) and affect the function of melanocytes in the stratum basale [84]. There is cumulative evidence that the combination of air pollutants with UVA escalates visible photodamage in the dermis [24].

Environmental metals, i.e. iron $(\mathrm{Fe})$, nickel (Ni), chromium $(\mathrm{Cr})$, copper $(\mathrm{Cu})$, zinc $(\mathrm{Zi})$, and arsenic (As) usually adhere to particulate matter [88]. Typically, PM2.5 include approx. 11-16\% of metal nanoparticles (size $<0.1 \mu \mathrm{m}$ ). These molecules can generate ROS and induce oxidative damage to skin cells [89]. Via the oxidative route, nanotoxins can induce apoptosis and cancer [90].

Ground-level ozone (GLO; $\left.\mathrm{O}_{3}\right)$ is another molecule that can induce oxidative stress in skin cells [3, 6, 91]. It is produced in a chemical reaction between $\mathrm{NO}$ and VOCs [25, 92]. At concentrations that occur in many polluted areas, ozone induces a variety of harmful effects in humans. Its high toxic effect on the skin has been demonstrated in various studies [93, 94]. The molecule acts through oxidation of unsaturated fatty acids. Moreover, ozone leads to depletion of skin lipophilic (i.e. approx. 70\% decrease in Vit. E) and hydrophilic antioxidants (i.e. Vit. C, urate) [73, 95]. High levels of ground ozone are also linked to the reduction in filaggrin, collagen, and elastin proteins [86].

Finally, the development of pathological skin conditions under air contamination is complex and involves autoimmune inflammation or activation of allergic inflammation [40]. Toxic activity of air pollutants on the skin was presented in Fig. 1.

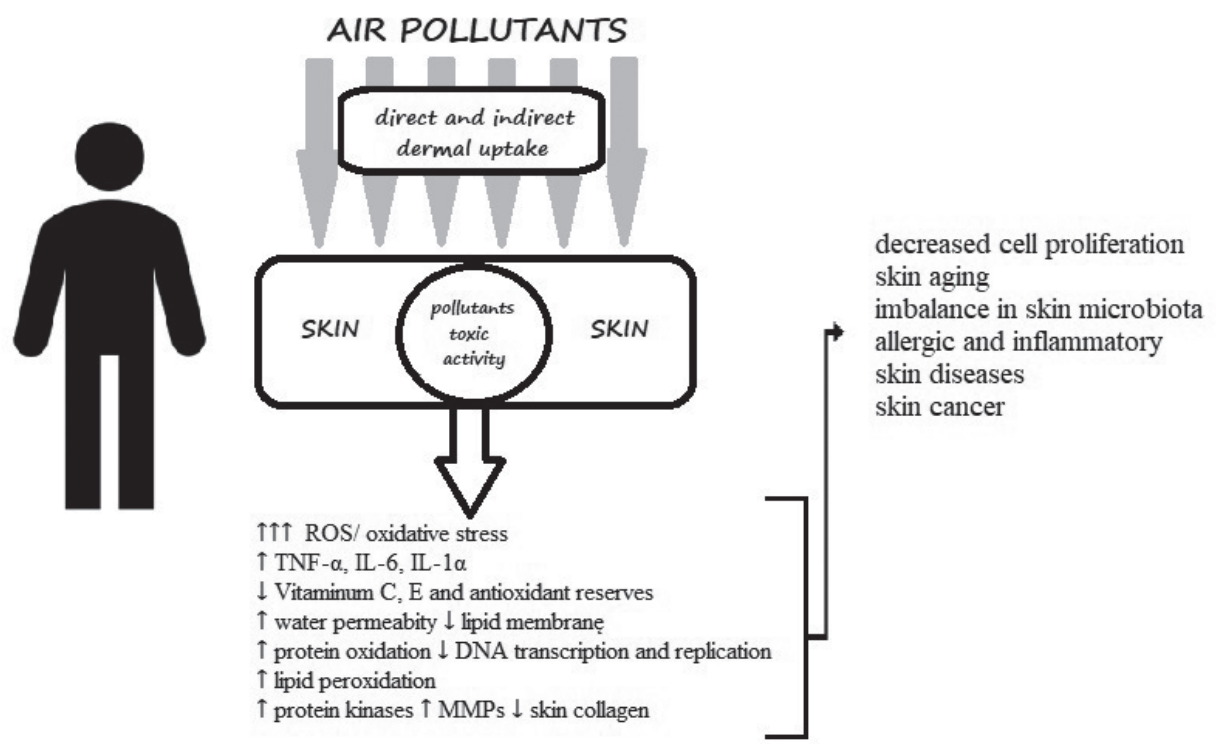

Fig. 1. Toxic activities of air pollutants on the skin. 


\section{Clinical Manifestations of the Effect of Air Pollutants on Skin}

In the epidermis, hazardous air contaminants induce destructive effects in the stratum corneum and result in modifications of the skin dermis [44, 54]. Permanent production of ROS under exposure of the skin to air toxins causes secretion of cytokines and cellular dysfunction. In consequence, breakdown of the skin epidermal lipid barrier is observed and a number of abnormal conditions, such as skin aging, imbalance in skin microbiota, inflammatory skin diseases, and skin cancer can be initiated [22, 77, 96-101]. Skin pathologies resulting from the air pollutants uptake with the damage mechanism are presented in Table 1 .

Table 1. Summary of the association between air pollutants and skin pathologies.

\begin{tabular}{|c|c|c|c|c|}
\hline Pollutant & Source & Mechanism of skin damage & $\begin{array}{l}\text { Skin effect and clinical } \\
\text { manifestation }\end{array}$ & References \\
\hline $\begin{array}{c}\text { Particulate matters - } \\
\text { PMs }\end{array}$ & $\begin{array}{l}\text { Forest fire, cooking, } \\
\text { biomass burning, diesel } \\
\text { engines, road dust, } \\
\text { industrial processes }\end{array}$ & $\begin{array}{c}\uparrow \text { ROS } \\
\uparrow \text { IL-6 } \\
\uparrow \text { IL-1 } \\
\uparrow \text { IL-8 } \\
\uparrow \text { inflammation } \\
\uparrow \text { keratinocytes apoptosis } \\
\uparrow \text { MMP-1, MMP-3 } \\
\downarrow \text { keratinocytes proliferation } \\
\downarrow \text { collagen synthesis } \\
\downarrow \text { filaggrin synthesis }\end{array}$ & $\begin{array}{c}\text { Irritation, inflammation, tissue } \\
\text { damage, skin dryness, effect on } \\
\text { the function of } \\
\text { melanocytes, acne, atopic } \\
\text { dermatitis, collagen } \\
\text { destruction, aging, hair loss, } \\
\text { impairment of skin t } \\
\text { hermoregulation }\end{array}$ & $\begin{array}{l}{[4,5,8,9} \\
\quad 91]\end{array}$ \\
\hline $\begin{array}{l}\text { Volatile organic } \\
\text { compounds - VOCs }\end{array}$ & $\begin{array}{c}\text { Aircraft emission, } \\
\text { household products, chemi- } \\
\text { cals, paints, cigarette smoke, } \\
\text { fragrances }\end{array}$ & $\begin{array}{l}\uparrow \operatorname{ROS} \\
\uparrow \text { IL-6 } \\
\uparrow \text { IL-1 }\end{array}$ & $\begin{array}{c}\text { Irritation, inflammation, tissue } \\
\text { damage, skin dryness, acne, } \\
\text { atopic dermatitis, cancer } \\
\text { initiation }\end{array}$ & $\begin{array}{c}{[5,9,21} \\
\quad 65]\end{array}$ \\
\hline $\mathrm{CO}_{2}, \mathrm{CO}$ & $\begin{array}{c}\text { Fossil-fuel, vehicle } \\
\text { emission CO include } \\
\text { fuel-burning devices, such as } \\
\text { automobiles, power genera- } \\
\text { tors, and boilers } \\
\end{array}$ & $\begin{array}{c}\uparrow \text { ROS } \\
\uparrow \text { IL-6 } \\
\uparrow \text { IL-1 } \\
\uparrow \text { IL-8 } \\
\uparrow \text { inflammation } \\
\end{array}$ & Acne, atopic dermatitis & {$[5,9,21]$} \\
\hline Nitrogen dioxide $\left(\mathrm{NO}_{2}\right)$ & $\begin{array}{l}\text { Wood burning, vehicle emis- } \\
\text { sion, waste burning }\end{array}$ & $\begin{array}{l}\uparrow \mathrm{ROS} \\
\uparrow \mathrm{IL}-6 \\
\uparrow \mathrm{IL}-1\end{array}$ & $\begin{array}{l}\text { Inflammation, tissue dam- } \\
\text { age skin dryness, acne, atopic } \\
\text { eczema }\end{array}$ & {$[5,9,83]$} \\
\hline Sulfur dioxide $\left(\mathrm{SO}_{2}\right)$ & $\begin{array}{c}\text { Vehicle emission, fuel incin- } \\
\text { eration, } \\
\text { crude oil and coal }\end{array}$ & $\begin{array}{c}\uparrow \mathrm{ROS} \\
\uparrow \text { inflammation }\end{array}$ & $\begin{array}{l}\text { Irritation, inflammation, } \\
\text { changes in pigmentation, col- } \\
\text { lagen destruction }\end{array}$ & {$[5,9,21]$} \\
\hline Ozone $\left(\mathrm{O}_{3}\right)$ & $\begin{array}{c}\text { Product of VOCs and NOx } \\
\text { with UV-photoactivation } \\
\text { interaction }\end{array}$ & $\begin{array}{c}\downarrow \text { collagen synthesis } \\
\downarrow \text { filaggrin synthesis } \\
\downarrow \text { elastin production } \\
\downarrow \text { Vit. E and C } \\
\quad \downarrow \text { urate }\end{array}$ & $\begin{array}{l}\text { Irritation, inflammation, tissue } \\
\text { damage, skin dryness, acne, } \\
\text { atopic dermatitis }\end{array}$ & {$[5,6,9]$} \\
\hline $\begin{array}{l}\text { Environmental metals, } \\
\text { i.e. iron }(\mathrm{Fe}), \text { nickel } \\
(\mathrm{Ni}), \text { chromium }(\mathrm{Cr}), \\
\text { cooper }(\mathrm{Cu}), \text { zinc }(\mathrm{Zi})\end{array}$ & $\begin{array}{c}\text { Battery manufacturing, } \\
\text { waste burning, aircraft } \\
\text { industry, minerals, metal } \\
\text { refineries }\end{array}$ & $\begin{array}{c}\uparrow \text { ROS } \\
\downarrow \text { Vit. E and C }\end{array}$ & $\begin{array}{l}\text { Irritation, inflammation, } \\
\text { allergy, cancerogenesis }\end{array}$ & {$[64,65]$} \\
\hline $\begin{array}{l}\text { Persistent organic com- } \\
\text { pounds - POPs }\end{array}$ & $\begin{array}{l}\text { Herbicides, pesticides, forest } \\
\text { fires, industrial processes }\end{array}$ & $\begin{array}{l}\uparrow \text { ROS } \\
\downarrow \text { Vit. E and C } \\
\uparrow \text { NADPH } \\
\uparrow \text { oxidases }\end{array}$ & $\begin{array}{c}\text { Irritation, inflammation, tissue } \\
\text { damage, atopic dermatitis, } \\
\text { allergy, cancer }\end{array}$ & {$[45,46,55]$} \\
\hline $\begin{array}{c}\text { Polyaromantic } \\
\text { hydrocarbons - PAHs }\end{array}$ & $\begin{array}{l}\text { Vehicle emission, cigarette } \\
\text { smoke, forest fire, grilling }\end{array}$ & $\begin{array}{c}\uparrow \text { ROS } \\
\downarrow \text { Vit. E and C } \\
\uparrow \text { NADPH } \\
\uparrow \text { cytochrome enzyme }\end{array}$ & $\begin{array}{l}\text { Irritation, inflammation, } \\
\text { allergy eczema }\end{array}$ & {$[40,73,84]$} \\
\hline
\end{tabular}

Abbreviations: IL-1 $\alpha$ : interleukin 1 $\alpha$, IL-6: interleukin 6, IL-8: interleukin 8; MMPs: matrix metalloproteinases; ROS: reactive oxygen species; NADPH: nicotinamide adenine dinucleotide phosphate 


\section{Skin Aging}

The link between skin aging and air pollution has been widely discussed [73, 102-105]. A cohort study published by Vierkötter et al. [21] pointed out a considerable increase in skin aging in women exposed to airborne pollution exceeding the levels considered safe for health, compared to those who inhabited clean areas. Strong correlations have been noted between exposure to traffic-related particles, tobacco smoke, and skin conditions [106]. These findings suggest that the skin of inhabitants of polluted areas looks thinner and may have age-associated reduced responsiveness to growth factors (i.e. epidermal growth factor - EGF). In the Chinese population, the increase in formation of wrinkles was associated with exposure to PM2.5 and $\mathrm{NO}_{2}$ [107]. Research across Caucasian and East Asians populations has shown that chronic exposure to trafficrelated air pollutants is manifested by deep wrinkles on the forehead, upper lip, dorsum of hands, and nuchae [108]. Several studies have reported that extrinsic skin aging signs are more frequent in areas with high groundlevel ozone levels [40, 41, 85]. Furthermore, it has been documented that long-term exposure to airborne pollutants can increase the number of age-associated pigment spots [109]. The airborne pollution-induced increase in the degree of age-associated pigmentation was higher after long-term exposure to PM2.5 than to PM10 [88, 108]. Moreover, association between $\mathrm{NO}_{2}$ exposure and pigment spots has been well-established [108]. Changes in skin pigmentation can be worsened by traffic-related toxins, which may significantly influence the function of melanocytes [21]. Hair loss is reported among the negative effects of skin premature aging related to airborne pollution [101]. Exposure to airborne toxins can cause a cumulative skin injury associated with long-term deterioration of dermal elasticity related to the decrease in the quantity of collagen and fibroblasts, which may worsen and accelerate skin aging [40, 43, 47]. Clinical manifestations of air pollutant stress in aging skin include xerosis of the epidermis [73, $103,105]$.

\section{Imbalance in Skin Microbiota}

Resident microbes found on the skin form persistent bacterial ecosystems and play an important role in supporting homeostasis and preventing the growth of harmful microbes [38, 110]. The human skin microbiota includes ca. 1000 bacterial species [111]. More advanced studies have found that skin microbes can produce antimicrobial proteins that activate the immune response of keratinocytes and prevents proliferation of skin pathogens [112]. Therefore, the balance in microbiota is necessary for maintenance of skin health. Numerous studies have shown that chronic contact with airborne pollutants undoubtedly disrupt the equilibrium of the skin microflora, causing a decrease in the number of microbial species $[100,110,113]$. For example, ground ozone reduces resident microbiota colonizing the skin by $50 \%$ [114]. PMs can also change the skin microbial community and/or modify its metabolism. As reported by Sowada et al. [115], organic molecules present in the atmospheric air can serve as carbon sources for the skin microbiota, i.e. polycyclic aromatic hydrocarbons are subject to complete or partial degradation. In consequence, the level of intermediates and excreted metabolites increases, and even activation of carcinogens is possible [80]. However, it should be underlined that our understanding of the association of air pollution with skin microbiota is still poor and requires further detailed investigations.

\section{Inflammatory Skin Diseases - Acne}

A number of studies have revealed that permanent exposure of skin to air pollutants with high levels of NOx and $\mathrm{CO}$ combined with climatic factors (low monthly relative humidity) can escalate the symptoms of inflammatory skin disorders [97,105]. Airborne toxins are known to disrupt the skin barrier function and increase the production of several proinflammatory chemicals, promoting inflammation [116]. Recently, several lines of evidence for the increase in acne cases in the Asian population exposed to elevated concentrations of air toxins have been reported [104]. In particular, air contamination with PM2.5, PM10, and $\mathrm{NO}_{2}$ can cause exacerbation of acne symptoms $[110,116]$. Interestingly, no such effects were noted in patients from areas with high levels of airborne $\mathrm{SO}_{2}$ [116]. There are reports indicating that the sebum levels in acne patients living in polluted urban areas are higher compared to those living in less polluted environments $[94,116]$. In the Shanghai area, intensified symptoms of acne are reported during days with elevated levels of particulate matters [94]. Air pollution with PMs, POPs, and gaseous and metal toxins damage the skin and, together with the accumulation of particles and chemicals on the skin surface, may simply aggravate acne symptoms [19]. This is related to disturbance in the skin barrier and disequilibrium in the skin microbiome, which results in proliferation of Propionibacterium acnes, i.e. a bacterium involved in acne inflammation and pathogenesis. As a result, acne lesion progression is observed [117].

\section{Inflammatory Skin Diseases - Atopic Dermatitis and Eczema}

Another inflammatory skin disease is atopic dermatitis. Airborne pollution is regarded as an important environmental factor for the prevalence of atopic dermatitis and other allergic skin symptoms [118]. There is ample evidence that skin exposure to airborne pollutants can specifically increase symptoms of atopic eczema. For example, a link was found between the levels of PM10, $\mathrm{NO}_{2}$, and $\mathrm{SO}_{2}$ and eczema signs in Chinese patients [105]. Furthermore, 
the manifestation of eczema symptoms correlates with certain environmental factors, such as relative humidity. Furthermore, the disease manifestation may differ considerably according to the region and season [119]. A similar correlation was found in Italian and Belarusian surveys [120, 121]. Data from meta-analysis unequivocally support the suggestion that there is a close link between air pollution and skin problems, including atopy [122]. In French children, atopic dermatitis was considerably associated with higher than normal concentrations of PM10, NO, and $\mathrm{CO}$ [118]. However, atopic dermatitis symptoms induced by air pollution can differ relative to the age and gender [22]. Another study showed a significant effect of VOCs in atopic dermatitis patients who suffered from skin dryness after exposure to VOCs. Presumably, the effect was associated with increased transepidermal water loss related to destruction of the skin barrier function. Skin eczema can be intensified by absorption of airborne metal molecules by the skin [123].

\section{Skin Cancer}

Carcinoma is one of the most severe environmentrelated skin pathologies [124]. The main environmental risk for skin cancer is UV radiation [23, 102]. Besides UV radiation, PAHs and metals are the major carcinogens related to air pollution [80, 125]. Even in concentrations below harmful toxic levels, PAHs can interact with UVA, generating ROS and contributing to the risk of cancer [24]. There is evidence that he longterm skin exposure to PAHs increases the risk of cancer [126]. Among POPs, PAHs are lipophilic and can easily infiltrate skin cells, binding to DNA and causing its damage [19]. Hence, these air pollutants are recognized as mutagens and/or carcinogens [124, 127]. Airborne metals are not biodegradable; they remain in cells for a long time and act as genotoxic agents, impairing the skin DNA repair capacity [128].

\section{Conclusion}

Air pollution is among major environmental health risk. Skin as an external barrier of the human body stays in direct and continuous contact with the environment and its pollutions. Skin pathologies not only result from internal disturbances in body metabolism and processes but also reflect air pollution. There is considerable evidence that air pollution increases oxidative stress in skin cells. The peroxidation/oxidation of specific skin macromolecules (lipids, proteins) brings important consequences at various levels and clearly leads to cytotoxic, pro-inflammatory, and immunological events, accelerates the skin ageing process, and causes imbalance in skin microbiota and skin disorders, i.e. inflammation (acne, atopic dermatitis, eczema), or even cancer.
However, there are no clear guidelines established for protecting the skin against airborne pollutants. The main strategy should concentrate on reducing the exposure, followed by restoration of the skin barrier function and an increase in antioxidant reserves. The treatment should also focus on reducing chronic inflammation. A forward-looking area of research is then to fill the gaps about the effect of air pollutants on the skin, including skin carcinogenesis.

\section{Acknowledgements}

We are grateful to Mrs Anna Zoń for help in English improvement and corrections.

\section{Conflict of Interest}

The author declares no conflict of interest.

\section{References}

1. KANWAR A.J. Skin barrier function. The Indian Journal of Medical Research. 147, 117, 2018.

2. PROKSCH E., BRANDNER J.M., JENSEN J.M. The skin: an indispensable barrier. Exp. Dermatol. 17, 1063, 2008.

3. GHORANI-AZAM A., RIAHI-ZANJANI B., BALALIMOOD M. Effects of air pollution on human health and practical measures for prevention in Iran. J. Res. Med. Sci. 21, 65, 2016.

4. PORTUGAL-COHEN M., ORON M., COHEN D., MA'OR Z. Antipollution skin protection - a new paradigm and its demonstration on two active compounds. Clin. Cosmet. Investig. Dermatol. 10, 185, 2017.

5. WORLD HEALTH ORGANIZATION. Air pollution. http://www.who.int/topics/air_pollution/en/. Accessed April 2020, 2017.

6. LEWTAS J. Airborne carcinogens. Pharmacol. Toxicol. 72, 55, 1993.

7. PEHNEC G., JAKOVLJEVIĆ I. Carcinogenic potency of airborne polycyclic aromatic hydrocarbons in relation to the particle fraction size. Int. J. Environ. Res. Public. Health. 7, 15, 2018.

8. EUROPEAN ENVIRONMENT AGENCY. Air quality in Europe - 2019 report. ISSN pp. 1977-8449, 2019.

9. HARRISON R.M., YIN J. Particulate matter in the atmosphere: which particle properties are important for its effects on health? Sci. Total Environ. 249, 85, 2000.

10. GIANNADAKI D., LELIEVELD J., POZZER A. Implementing the US air quality standard for $\mathrm{PM}_{2.5}$ worldwide can prevent millions of premature deaths per year. Environmental Health. 15, 88, 2016.

11. CORREIA A.W.C., POPE A., DOCKERY D.W., WANG Y., EZZATI M., DOMINICI F. The effect of air pollution control on life expectancy in the United States: an analysis of 545 US counties for the period 2000 to 2007. Epidemiology. 24, 23, 2013.

12. GHASEMI F.F., DOBARADARAN S., SAEEDI R., NABIPOUR I., NAZMARA S., ABADI D.R., ARFAEINIA H., RAMAVANDI B., SPITZ J., MOHAMMADI M.J., KESHTKAR M. Levels and 
ecological and health risk assessment of PM 2.5-bound heavy metals in the northern part of the Persian Gulf. Environ Sci Pollut Res Int. 27, 5305, 2020.

13. MEISTER K., JOHANSSON C., FORSBERG B. Estimated short-term effects of coarse particles on daily mortality in Stockholm, Sweden. Environ. Health Perspect. 120, 431, 2012.

14. SUN Z., ZHU D. Exposure to outdoor air pollution and its human health outcomes: A scoping review. PLoS One. 14, e0216550, 2019.

15. KATSOUYANNI K., TOULOUMI G., SAMOLI E., GRYPARIS A., LE TERTRE A., et al. Confounding and effect modification in the short-term effects of ambient particles on total mortality: results from 29 European cities within the APHEA2 project. Epidemiology. 12, 521, 2001.

16. MADISON K.C. Barrier function of the skin: "la raison d'etre" of the epidermis. J. Invest. Dermatol. 121, 231, 2003.

17. BICKERS D.R., ATHAR M. Oxidative stress in the pathogenesis of skin disease. J. Invest. Dermatol. 126, 2565, 2006.

18. CRAVELLO B., FERRI, A. Relationships between skin properties and environmental parameters. Skin Res. Technol. 14, 180, 2008.

19. DRAKAKI E., DESSINIOTI C., ANTONIOU C.V. Air pollution and the skin. Front. Environ. Sci., 2, 11, 2014.

20. PURI P., NANDAR S.K., KATHURIA S., RAMESH, V. Effects of air pollution on the skin: A review. Indian J. Dermatol. Venereol. Leprol. 83, 415, 2017.

21. VIERKÖTTER A., SCHIKOWSKI T., RANFT U., SUGIRI D., MATSUI M., KRÄMER U., KRUTMANN J. Airborne particle exposure and extrinsic skin aging. J. Invest. Dermatol. 130, 2719, 2010.

22. KIM E.H., KIM S., LEE J.H., KIM J., HAN Y. et al. Indoor air pollution aggravates symptoms of atopic dermatitis in children. PLoS One, 10, e0119501, 2015.

23. D'ORAZIO J., JARRETT S., AMARO-ORTIZ A., SCOTT T. UV radiation and the skin. Int. J. Mol. Sci. 14, 12222, 2013.

24. BURKE K.E., WEI H. Synergistic damage by UVA radiation and pollutants. Toxicol Ind Health. 25, 219, 2009.

25. MARROT L. Pollution and sun exposure: A deleterious synergy. Mechanisms and opportunities for skin protection. Curr. Med. Chem. 25, 1, 2018.

26. YOUSEF H., ALHAJJ M., SHARMA S. Anatomy, Skin (Integument), Epidermis. (Updated 2019 Jun 12). In: StatPearls [(Internet). Treasure Island (FL): StatPearls Publishing; 2019 Jan. Available from: https://www.ncbi. nlm.nih.gov/books/NBK470464/, 2019.

27. HAAKE A., SCOTT G.A., HOLBROOK K.A. Structure and function of the skin: overview of the epidermis and dermis, in: Freinkel, R.K., Woodley, D.T. (Eds.), The Biology of the Skin, New York, Taylor \& Francis, 19, 2001.

28. TAGAMI H. Location-related differences in structure and function of the stratum corneum with special emphasis on those of the facial skin. Int. J. Cosmet. Sci. 30, 413, 2008.

29. ECKHART L., LIPPENS S., TSCHACHLER E., DECLERCQ W. Cell death by cornification. Biochim Biophys Acta. 1833, 3471, 2013.

30. SLOMINSKI A.T., ZMIJEWSKI M.A., SKOBOWIAT C., ZBYTEK B., SLOMINSKI R.M., STEKETEE J.D. Sensing the environment: regulation of local and global homeostasis by the skin's neuroendocrine system. Adv. Anat. Embryol. Cell Biol. 212, v-115, 2012.
31. KIM S., COULOMBE P.A. Intermediate filament scaffolds fulfill mechanical, organizational, and signaling functions in the cytoplasm. Genes Dev. 21, 1581, 2007.

32. WOODLEY D.T., WYSONG A., DECLERCK B., CHEN M., LI W. Keratinocyte migration and a hypothetical new role for extracellular heat shock protein 90 alpha in orchestrating skin wound healing. Adv. Wound Care. 4, 203, 2015.

33. HARDER J., SCHRÖDER J.M., GLÄSER R. The skin surface as antimicrobial barrier: Present concepts and future outlooks. Exp. Dermatol. 22, 1, 2013.

34. NEMES Z., STEINERT P.M. Bricks and mortar of the epidermal barrier. Exp. Mol. Med. 31, 5, 1999.

35. KIM J.H., AHN B., CHOI S.G., IN S., GOH A.R., PARK S.G., LEE C.K., KANG N.G. Amino acids disrupt calcium-dependent adhesion of stratum corneum. PLoS One. 14, 2019.

36. MENON G.K., CLEARY G.W., LANE M.E. The structure and function of the stratum corneum. Intern. J. Pharm. 435, 3, 2012.

37. FEINGOLD K.R., JIANG Y.J. The mechanisms by which lipids coordinately regulate the formation of the protein and lipid domains of the stratum corneum: Role of fatty acids, oxysterols, cholesterol sulfate and ceramides as signaling molecules. Dermatoendocrinol. 3, 113, 2011.

38. BOSKO C.A. Skin barrier insights: from bricks and mortar to molecules and microbes. J. Drugs Dermatol. 18, 63, 2019.

39. HEATH W.R., CARBONE F.R. The skin-resident and migratory immune system in steady state and memory: innate lymphocytes, dendritic cells and $\mathrm{T}$ cells. Nat. Immunol. 14, 978, 2013.

40. MAAROUF M., MAAROUF C.L., YOSIPOVITCH G., SHI V.Y. The impact of stress on epidermal barrier function: an evidence-based review. Br. J. Dermatol. 181, 1129, 2019.

41. VAN SMEDEN J., BOUWSTRA J.A. Stratum corneum lipids: Their role for the skin barrier function in healthy subjects and atopic dermatitis patients. Curr. Probl. Dermatol. 49, 8, 2016.

42. KELLY F.J., FUSSELL J.C. Linking ambient particulate matter pollution effects with oxidative biology and immune responses. Ann NY Acad Sci., 1340, 84, 2015.

43. ELIAS P.M., HATANO Y., WILLIAMS M.L. Basis for the barrier abnormality in atopic dermatitis: Outside-insideoutside pathogenic mechanisms. J Allergy Clin Immunol. 121, 1337, 2008.

44. RIZZO W.B. The role of fatty aldehyde dehydrogenase in epidermal structure and function. Dermatoendocrinol. 3, 91, 2011.

45. ELIAS P.M. Physiologic lipids for barrier repair in dermatology, in: Draelos, Z.D., (Ed.), Cosmeceuticals. 1st ed. Philadelphia, Elsevier-Saunders, 63, 2005.

46. IMOKAWA G., ABE A., JIN K., HIGAKI Y., KAWASHIMA M., HIDANO A. Decreased level of ceramides in stratum corneum of atopic dermatitis: an etiologic factor in atopic dry skin? J. Invest. Dermatol. 96, 523, 1991.

47. MEHREL T., HOHL D., ROTHNAGEL J.A., LONGLEY M.A., BUNDMAN D., ET AL. Identification of a major keratinocyte cell envelope protein, loricrin. Cell. 61, 1103, 1990.

48. VERMEIJ W.P., ALIA A., BACKENDORF C. ROS quenching potential of the epidermal cornified cell envelope. J. Invest. Dermatol. 131, 1435, 2011. 
49. RUHRBERG C., HAJIBAGHERI M.A., PARRY D.A., WATT F.M. Periplakin, a novel component of cornified envelopes and desmosomes that belongs to the plakin family and forms complexes with envoplakin. J. Cell Biol. 139, 1835, 1997.

50. BROWN S.J., MCLEAN W.H. One remarkable molecule: filaggrin. J. Investig. Dermatol. Symp. Proc. 132, 751, 2011.

51. STEINERT P.M., CANTIERI J.S., TELLER D.C., LONSDALE-ECCLES J.D., DALE B.A. Characterization of a class of cationic proteins that specifically interact with intermediate filaments. Proc. Nat. Acad. Sci. USA. 78, 4097, 1981.

52. PALMER C.N., IRVINE A.D., TERRONKWIATKOWSKI A., ZHAO Y., LIAO H., ET AL. Common loss-of-function variants of the epidermal barrier protein filaggrin are a major predisposing factor for atopic dermatitis. Nat. Genet. 38, 441, 2006.

53. HAUSMANN C., ZOSCHKE C., WOLFF C., DARVIN M.E., SOCHOROVÁ M., KOVÁČIK A., SCHÄFERKORTING M. Fibroblast origin shapes tissue homeostasis, epidermal differentiation, and drug uptake. Sci. Rep. 9, 2913, 2019.

54. SANDILANDS A., SUTHERLAND C., IRVINE A.D., MCLEAN W.H. Filaggrin in the frontline: role in skin barrier function and disease. Journal of Cell Sci. 122, $1285,2009$.

55. BROWN S.J., RELTON C.L., LIAO H., ZHAO Y., SANDILANDS A., WILSON I.J., BURN J., REYNOLDS N.J., MCLEAN W.H., CORDELL H.J. Filaggrin null mutations and childhood atopic eczema: a populationbased case-control study. J. Allergy Clin. Immun. 121, 940, 2008.

56. MCALEER M.A., IRVINE A.D. The multifunctional role of filaggrin in allergic skin disease. J. Allergy Clin. Immunol. 131, 280, 2013.

57. SEVILLA L.M., NACHAT R., GROOT K.R., KLEMENT J.F., UITTO J., DJIAN P., MÄÄTTÄ A., WATT F.M. Mice deficient in involucrin, envoplakin, and periplakin have a defective epidermal barrier. J. Cell Biol. 179, 1599, 2007.

58. YOSHIDA K., YOKOUCHI M., NAGAO K., ISHII K., AMAGAI, M., KUBO, A. Functional tight junction barrier localizes in the second layer of the stratum granulosum of human epidermis. Dermatol. Sci. 71, 89, 2013.

59. KABASHIMA K., HONDA T., GINHOUX F., EGAWA, G. The immunological anatomy of the skin. Nat Rev Immunol. 19, 19, 2019.

60. NGUYEN A.V., SOULIKA A.M. The dynamics of the skin's immune system. Inter. J. Mol. Sci. 20, 1811, 2019.

61. HOATH S.B., LEAHY D.G. The organization of human epidermis: functional epidermal units and phi proportionality. J. Invest. Dermatol. 121, 1440, 2003.

62. HÄNEL K.H., CORNELISSEN C., LÜSCHER B., BARON J.M. Cytokines and the skin barrier. Intern. J. Mol. Sci. 14, 6720, 2013.

63. PARRADO C., MERCADO-SAENZ S., PEREZ-DAVO A., GILABERTE Y., GONZALEZ S., JUARRANZ A. Environmental Stressors on Skin Aging. Mechanistic Insights. Front. Pharmacol. 10, 759, 2019.

64. DONALDSON K., BESWICK P.S. Free radical activity associated with the surface of the particles: a unifying factor in deter-mining biological activity. Toxicol. Lett. 88, 293, 1996.

65. SIVULKA D.J., CONARD B.R., HALL G.W., VINCENT J.H. Species-specific inhalable exposures in the nickel industry: a new approach for deriving inhalation occupational exposure limits. Regul Toxicol Pharmacol. 48, 19, 2007.

66. JIN S.P., LI Z., CHOI E.K., LEE S., KIM Y.K., SEO E.Y., CHUNG J.H., CHO S. Urban particulate matter in air pollution penetrates into the barrier-disrupted skin and produces ROS-dependent cutaneous inflammatory response in vivo. J. Dermatol. Sci. pii: S0923-1811 30202$0,2018$.

67. LADEMANN J., SCHAEFER H., OTBERG N., TEICHMANN A., BLUME-PEYTAVI U., STERRY W. Penetration of microparticles into human skin. Hautarzt. 55, 1117, 2004.

68. LUECKE S., BACKLUND M., JUX B., ESSER C., KRUTMANN J., RANNUG A. The aryl hydrocarbon receptor (AHR), a novel regulator of human melanogenesis. Pigment Cell Melanoma Res. 23, 828, 2010.

69. CHOI H., SHIN D.W., KIM W., DOH S.J., LEE S.H., $\mathrm{NOH}$ M. Asian dust storm particles induce a broad toxicological. Transcriptional program in human epidermal keratinocytes. Toxicol. Lett. 200, 92, 2011.

70. BORGIE M., LEDOUX F., VERDIN A., CAZIER F., GREIGE H., SHIRALI P., COURCOT D., DAGHER Z. Genotoxic and epigenotoxic effects of fine particulate matter from rural and urban sites in Lebanon on human bronchial epithelial cells. Environ Res. 136, 352, 2015.

71. WÖLFLE U., SEELINGER G., BAUER G., MEINKE M. C., LADEMANN J., SCHEMPP C.M. Reactive molecule species and antioxidative mechanisms in normal skin and skin aging. Skin Pharmacol. Physiol. 27, 316, 2014.

72. URSINI F., MAIORINO M., FORMAN H.J. Redox homeostasis: the golden mean of healthy living. Redox Biol. 8, 205, 2016.

73. VALACCHI G., STICOZZI C., PECORELLI A., CERVELLATI F., CERVELLATI C., MAIOLI E. Cutaneous responses to environmental stressors. Ann New York Acad Sci. 1271, 75, 2012.

74. BARREGARD L., SÄLLSTEN G., GUSTAFSON P., ANDERSSON L., JOHANSSON L., BASU S., STIGENDAL L. Experimental exposure to woodsmoke particles in healthy humans: effects on markers of inflammation, coagulation, and lipid peroxidation. Inhal. Toxicol. 18, 845, 2006.

75. XU H., ZHENG Y.W., LIU Q., LIU L.P., LUO F.L., ZHOU H.C., ISODA H., OHKOHCHI N., LI Y.M. Reactive Oxygen Species in skin repair, regeneration, aging, and inflammation, Reactive Oxygen Species (ROS) in Living Cells. Filip, C., and Albu E., (Eds). IntechOpen, Available from: https://www.intechopen.com/books/ reactive-oxygen-species-ros-in-living-cells/reactiveoxygen-species-in-skin-repair-regeneration-aging-andinflammation, 2017.

76. BRIGANTI S., PICARDO M. Antioxidant activity, lipid peroxidation and skin diseases. What's new. J. Eur. Acad. Dermatol. Venereol. 17, 663, 2003.

77. YADAV D.K., KUMAR S., CHOI E.H., CHAUDHARY,S., KIM M.H. Molecular dynamic simulations of oxidized skin lipid bilayer and permeability of reactive oxygen species. Sci. Rep. 9, 4496, 2019.

78. MCCARTHY J.T., PELLE E., DONG K., BRAHMBHATT K., YAROSH D., PERNODET N. Effects of ozone in normal human epidermal keratinocytes. Exp. Dermatol. 22, 360, 2013.

79. MEHTA M., CHEN L.C., GORDON T., ROM W., TANG M.S. Particulate matter inhibits DNA repair and enhances mutagenesis. Mutat Res. 657, 116, 2008. 
80. POLLET M., SHAIK S., MESCHER M., FRAUENSTEIN K., TIGGES J., et al. The AHR represses nucleotide excision repair and apoptosis and contributes to UVinduced skin carcinogenesis. Cell Death Differ. 25, 1823, 2018.

81. RITTIÉ L., FISHER G.J. UV-light-induced signal cascades and skin aging. Ageing Res. Rev. 1, 705, 2002.

82. KIM H., BERNSTEIN J. A. Air pollution and allergic disease. Curr. Allergy Asthma Rep. 9, 128, 2009.

83. USHIO H., NOHARA K., FUJIMAKI H. Effect of environmental pollutants on the production of proinflammatory cytokines by normal human dermal keratinocytes. Toxicol. Lett. 105, 17, 1999.

84. KRUTMAN J., LIU W., LI L., PAN X., CRAWFORD M., SORE G., SEITE S. Pollution and skin: From epidemiological and mechanistic studies to clinical implications. J. Dermatol. Sci. 76, 163, 2014.

85. TANAKA H., OKADA T., KONISHI H., TSUJI T. The effects of reactive oxygen species on the biosynthesis of collagen and glycosaminoglycans in cultured human dermal fibroblasts. Arch. Dermatol. Res. 285, 352, 1993.

86. WEBER S.U., THIELE J.J., CROSS C.E., PACKER L. Vitamin C, uric acid, and glutathione gradients in murine stratum corneum and their susceptibility to ozone exposure. J. Invest. Dermatol. 113, 1128, 1999.

87. VOEGELI R., RAWLINGS A.V., DOPPLER S., SCHREIER T. Increased basal transepidermal water loss leads to elevation of some but not all stratum corneum serine proteases. Int. J. Cosmet. Sci. 30, 435, 2008.

88. DING A., YANG Y., ZHAO Z., HULS A., VIERKOTTER A., et al., Indoor PM2.5 exposure affects skin aging manifestation in a Chinese population. Sci. Rep. 7, 15329, 2017.

89. MAGNANI N.D., MURESAN X.M., BELMONTE G., CERVELlATI F., STICOZZI C., PECORELLI A., MIRACCO C., MARCHINI T., EVELSON P., VALACCHI G. Skin damage mechanisms related to airborne particulate matter exposure. Toxicol. Sci. 149, 227, 2016.

90. FU P.P., XIA Q., HWANG H.M., RAY P.C., YU H. Mechanisms of nanotoxicity: generation of reactive oxygen species. J. Food Drug Anal. 22, 64, 2014.

91. ENGLERT N. Fine particles and human health - a review of epidemiological studies. Toxicol. Lett. 149, 235, 2004.

92. MADRONICH S., WAGNER M., GROTH P. Influence of tropospheric ozone control on exposure to ultraviolet radiation at the surface. Environ. Sci. Technol. 45, 6919, 2011.

93. LEFEBVRE M.A., PHAM D.M., BOUSSOUIRA B., BERNARD D., CAMUS C., NGUYEN Q.L. Evaluation of the impact of urban pollution on the quality of skin: a multicentre study in Mexico. Int. J. Cosm. Sci. 37, 329, 2015.

94. LEFEBVRE M.A., PHAM, D. M., BOUSSOUIRA B., QIU H., YE C., LONG X., CHEN R., GU W., LAURENT A., NGUYEN Q.L. Consequences of urban pollution upon skin status. A controlled study in Shanghai area. Int. J. Cosm. Sci. 38, 217, 2016.

95. VALACCHI G., FORTINO V., BOCCI V. The dual action of ozone on the skin. Br. J. Dermatol. 153, 1096, 2005.

96. AHN K. The role of air pollutants in atopic dermatitis. J. Allergy Clin. Immunol. 134, 993, 2014.

97. ANNESI-MAESANO I., MOREAU D., CAILLAUDC D., LAVAUDD F.O., MOULLECE Y.L., et al. Residential proximity fine particles related to allergic sensitisation and asthma in primary school children. Respir. Med. 101, 1721, 2007.

98. BRAUER M., HOEK G., SMIT H.A., DE JONGSTE J.C., GERRITSEN J., POSTMAE D.S., KERKHOF M, BRUNEKREEF B. Air pollution and development of asthma, allergy and infections in a birth cohort. Eur. Respir. J. 29, 879, 2007.

99. SZYSZKOWICZ M., KOUSHA T., VALACCHI G. Ambient air pollution and emergency department visits for skin conditions. Glob. Dermatol. 3, 323, 2016.

100. ARAVIISKAIA E., BERARDESCA E., BIEBER T., GONTIJO G., SANCHEZ VIERA M., MARROT L., DRENO B. The impact of airborne pollution on skin. J. Eur. Acad. Dermatol. Venereol. 33, 1496, 2019.

101. MANCEBO S.E., WANG S.Q. Recognizing the impact of ambient air pollution on skin health. J. Eur. Acad. Dermatol. Venereol. 29, 2326, 2015.

102. BURKE K.E. Mechanisms of aging and development A new understanding of environmental damage to the skin and prevention with topical antioxidants. Mech Ageing Dev. 172, 123, 2018.

103. DENDA M., SATO J., MASUDA Y., TSUCHIYA T., KOYAMA J., KURAMOTO M., ELIAS P.M., FEINGOLD K.R. Exposure to a dry environment enhances epidermal permeability barrier function. J. Invest. Dermatol. 111, 858, 1998.

104. KRUTMANN J., MOYAL D., LIU W., KANDAHARI S., LEE G.S., ET AL. Pollution and acne: is there a link? Clin Cosmet Investig Dermatol. 10, 199, 2017.

105. LEE J.H., LEE H.S., PARK M.R., LEE S.W., KIM E.H., et al. Relationship between indoor air pollutant levels and residential environment in children with atopic dermatitis. Ann. Allergy Asthma Immunol. 6, 517, 2014.

106. SCHROEDER P., SCHIEKE S.M., MORITA A. Premature skin aging by infrared radiation, tobacco smoke and ozone, in Skin Aging, eds B. A. Gilchrest and J. Krutmann (Berlin; Heidelberg: Springer), 45, 2006.

107. LI M.Z., VIERKÖTTER A., SCHIKOWSKI T., HÜLS A., DING A. et al. Epidemiological evidence that indoor air pollution from cooking with solid fuels accelerates skin aging in Chinese women. J. Dermatol. Sci. 79, 148, 2015.

108. HÜLS A., VIERKOTTER A., GAO W., KRAMER U., YANG Y., ET AL. Traffic-related air pollution contributes to development of facial lentigines: Further Epidemiological Evidence from Caucasians and Asians. J. Invest. Dermatol. 136, 1053, 2016.

109. KENNEDY C., BASTIAENS M.T., BAJDIK C.D., WILLEMZE R., WESTENDORP R.G., BOUWES BAVINCK J.N. Effect of smoking and sun on the aging skin. J. Invest. Dermatol. 120, 548, 2003.

110. DRENO B., ARAVIISKAIA E., BERARDESCA E., GONTIJO G., SANCHEZ V.M.E.T., et al. Microbiome in healthy skin, update for dermatologists. J Eur Acad Dermatol Venereol. 30, 2038, 2016.

111. GRICE E.A., KONG H.H., CONLAN S., DEMING C.B., DAVIS J., et al. Topographical and temporal diversity of the human skin microbiome. Science. 324, 1190, 2009.

112. COGEN A.L., NIZET V., GALLO R.L. Skin microbiota: a source of disease or defence? Br J Dermatol, 158, 442, 2008.

113. GOU H., LU J., LI S., TONG Y., XIE C., ZHENG X. Assessment of microbial communities in PM1 and PM10 of Urumqi during winter. Environ Pollut. 214, 202, 2016.

114. HE Q.C., TAVAKKOL A., WIETECHA K., BEGUMGAFUR R., ANSARI S.A., POLEFKA T. Effects 
of environmentally realistic levels of ozone on stratum corneum function. Int. J. Cosmet. Sci. 28, 349, 2006.

115. SOWADA J., SCHMALENBERGER A., EBNER I., LUCH A., TRALAU T. Degradation of benzo[a]pyrene by bacterial isolates from human skin. FEMS Microbiol. Ecol. 88, 129, 2014.

116. LIU W., PAN X., VIERKOTTER A., GUO Q., WANG $X$., et al. A time-series study of the effect of air pollution on outpatient visits for acne vulgaris in Beijing. Skin Pharmacol. Physiol. 31, 107, 2018.

117. DRENO B. What is new in the pathophysiology of acne, an overview. J. Eur. Acad. Dermatol. Venereol. 31, 8, 2017.

118. JEDRYCHOWSKI W., PERERA F., MAUGERI U., MROZEK-BUDZYN D., MILLER R.L., FLAK E., MROZ E., JACEK R., SPENGLER J.D. Effects of prenatal and perinatal exposure to fine air pollutants and maternal fish consumption on the occurrence of infantile eczema. Int. Arch. Allergy Immunol. 155, 275, 2011.

119. LI A., FAN L., XIE L., REN Y., LI L. Associations between air pollution, climate factors and outpatient visits for eczema in West China Hospital, Chengdu, south-western China: a time series analysis. J. Eur. Acad. Dermatol. Venereol. 32, 486, 2018.

120. PESCE G., MARCON A., CAROSSO A., ANTONICELli L., CAZZOLETTI L., et al. Adult eczema in Italy: prevalence and associations with environmental factors. J. Eur. Acad. Dermatol. Venereol. 29, 1180, 2015.

121. BELUGINA I.N., YAGOVDIK N.Z., BELUGINA O.S., BELUGIN S.N. Outdoor environment, ozone, radionuclide-associated aerosols and incidences of infantile eczema in Minsk, Belarus. J. Eur. Acad. Dermatol. Venereol. 32, 1977, 2018.
122. NGOC L.T.N., PARK D., LEE Y., LEE Y.C. Systematic review and meta-analysis of human skin diseases due to particulate matter. Int. J. Environ. Res. Public. Health. 14, 1458, 2017.

123. HUSS-MARP J., EBERLEIN-KÖNIG B., BREUER K., MAIR S., ANSEL A., DARSOW U., KRÄMER U., MAYER E., RING J., BEHRENDT H. Influence of short-term exposure to airborne Der $\mathrm{p} 1$ and volatile organic compounds on skin barrier function and dermal blood flow in patients with atopic eczema and healthy individuals. Clin. Exp. Allergy. 36, 338, 2006.

124. BAUDOUIN C., CHARVERON M., TARROUX R., AND GALL Y. Environmental pollutants and skin cancer. Cell Biol. Toxicol. 18, 341, 2002.

125. IDANI E., GERAVANDI S., AKHZARI M., GOUDARZI G., ALAVI N., YARI A.R., MEHRPOUR M., KHAVASI M., BAHMAEI J., BOSTAN H., DOBARADARAN S. Characteristics, sources, and health risks of atmospheric PM10-bound heavy metals in a populated middle eastern city. Toxin Reviews. 10, 1, 2018.

126. STOCKHOLM CONVENTION. Stockholm Convention on Persistent Organic Pollutants (POPs), November 2011.

127. GOUDARZI G., GERAVANDI S., ALAVI N., IDANI E., SALMANZADEH S., YARI A.R., JAMSHIDI F., MOHAMMADI M.J., RANJBARZADEH A., ALAMDARI F.A., DARABI F. Association between cancer risk and polycyclic aromatic hydrocarbons' exposure in the ambient air of Ahvaz, southwest of Iran. Int J Biometeorol. 62, 1461, 2018.

128. CHIANG-WEN L., LIN Z.C., HU S.C., CHIANG Y.C., HSU L.F., LIN Y.C., LEE I.T., TSAI M.H., FANG J.Y. Urban particulate matter down-regulates filaggrin via COX2 expression/PGE2 production leading to skin barrier dysfunction. Sci. Rep. 6, 79, 2016. 